\title{
PERSEVERANCE WITHIN AN ORDO SALUTIS
}

\author{
Ján Henžel
}

\begin{abstract}
Summary
Even the most exhaustive definitions of distinct elements of salvation cannot provide a comprehensive picture unless they are set in relationship to each other. In the following, we shall seek to put these distinct elements in an order. We shall do that with the initiating elements of the spiritual life, which will then enable us to link them with the progress of the believer's life. That in turn will prepare the ground to redefine the doctrine of the perseverance of believers within such a revised order.
\end{abstract}

\section{Perseverance within an Ordo Salutis}

Order of salvation (Lat. ordo salutis) is a category with a long history understood in a number of different ways. It may be defined in the wider sense as encompassing the whole history of divine salvation beginning with the divine eternal decree followed by Christ's accomplishment, the Spirit's application and culminating in the eschatological consummation of salvation. It has become more common to define ordo salutis in the narrower sense as encompassing the historical application of Christ's redemption to particular persons by the Holy Spirit. Speaking about ordo salutis in this article we shall use it in the latter narrower sense. ${ }^{1}$ We want to affirm the orderliness that is emphasised in the definition of the Scottish theologian S. B. Ferguson:

When applied to the application of redemption, ordo salutis denotes the orderly arrangement of the various aspects of salvation in its bestowal on men and women. In particular it seeks to answer this question: "In what

1 Sometimes English speakers also talk of the 'way of salvation' and the German speakers of Heilsaneignung or Heilsordnung of which the former is to be preferred for our purposes. 
ways are the various aspects of the application of redemption (such as justification, regeneration, conversion and sanctification) related to each other?" Discussions of ordo salutis thus attempt to unpack the inner coherence and logic of the Spirit's application of the work of Christ. ${ }^{2}$

Even ordo salutis understood in this sense requires a much more detailed definition which we shall give later.

First at least a sketchy development of the idea is appropriate here. The early apostolic and church fathers were preoccupied by objective salvation. Augustine's teaching on internal grace made a substantial contribution to the doctrine of subjective salvation. Although he speaks of different movements of the Spirit, he left ordo salutis quite undeveloped. He used terms like regeneratio, vivificatio, renovatio and sanctificatio as synonyms for justification. If we are to discern an ordo salutis at all, we have to see it within his neoplatonic framework of the Christian life expressed in the following chain:

But by the law comes the knowledge of sin; by faith comes the obtaining of grace against sin; by grace comes the healing of the soul from sin's sickness; by the healing of the soul comes freedom of choice; by freedom of choice comes the love of righteousness; by the love of righteousness comes the working of the law. ${ }^{3}$

Neither does Thomas Aquinas show the connection between Christ's earning salvation in the past and its application to individuals in time, except in the sacraments.

Though the Reformers carefully distinguished between different elements and stages of the process of salvation, even they did not present a systematic treatment of ordo salutis. We find the term first in J. H. Bullinger's De gratia Dei iustificante, in 1554, but without any special emphasis. ${ }^{4}$ Calov in 1677 and Quenstedt in 1685 did not use the term but 'gave a systematic treatment of different moments of the Ordo Salutis under a unifying head'. ${ }^{5}$ Calov names the following order: 'vocatio (illuminatio, regeneratio, conversio), iustificatio, fides iustificans, poenitentia, unio mystica, sanctificatio and glorificatio'. ${ }^{6}$

2 S. B. Ferguson, The Holy Spirit (Leicester: IVP, 1996): 96.

3 Augustine, The Spirit and the Letter, ch. 52, in Library of Christian Classics, VIII.236.

4 See O. Weber, Grundlagen der Dogmatik (2 vols.; Berlin: Evangelische Verlangsanstalt, 1969): 2.379 fn. 1. Thus nearly 200 years before J. Carpov; see H. Kuiper, By Grace Alone: A Study in Soteriology (Grand Rapids: Eerdmans, 1955): 19.

5 Kuiper, By Grace, 19.

6 In fn. 3 of Weber, Grundlagen, 2.378. 
Since J. Carpov in 1737, the systematic treatment of different elements of salvific application has been called the ordo salutis.

From the very beginning the particular orders are different. Before coming to a more detailed examination of various Reformed views of ordo, we shall describe the other main views. D. G. Bloesch surveys the doctrine in a wide ecumenical context. ${ }^{7} \mathrm{H}$. Kuiper may be right that 'strictly speaking, the Roman Catholics have no doctrine of the Ordo Salutis'. ${ }^{8}$ They certainly recognise and teach about the process and different stages of salvation. However it is not the Holy Spirit but the church which supplies to men all the grace needed for their salvation through sacraments. In that sense it is not difficult to discern an order of salvation from the Catechism of the Catholic Church: it starts with faith in Jesus Christ. Believing in Jesus Christ and in the one who sent him for our salvation is necessary for obtaining that salvation. 'Since "without faith it is impossible to please [God]" and to attain to the fellowship of his sons, therefore without faith no one has ever attained justification, nor will anyone obtain eternal life "but he who endures to the end". ${ }^{9}$ This justification is attained through baptism.

Holy Baptism is the basis of the whole Christian life, the gateway to life in the Spirit (vitae spiritualis ianua), and the door which gives access to the other sacraments. Through Baptism we are freed from sin and reborn as sons of God; we become members of Christ, are incorporated into the Church and made sharers in her mission: "Baptism is the sacrament of regeneration through water in the word." 10

The acquired justification is to be preserved and increased. ${ }^{11}$ The process of being saved may be thwarted by a person's mortal $\sin { }^{12}$ Thus the sinner must turn to the sacrament of penance. ${ }^{13}$ The moment of death is the moment of truth for a Catholic. At this particular judgement God decides his final destiny. ${ }^{14}$ If he preserved grace in his soul until the end, he has achieved final perseverance. ${ }^{15}$ However before he

\footnotetext{
7 D. G. Bloesch, Essentials of Evangelical Theology (2 vols.; New York: Harper \& Row, 1978-1979): 2.41-47.

8 Kuiper, By Grace, 20.

9 Catechism, § 161.

10 Catechism, $§ 1213$.

11 Catechism, § 1392.

12 Catechism, $\S \S 1033,1861,1874$.

13 Catechism, $\S \S 1446,1856$.

14 Catechism, §§ 1005, 1013, 1022, 1051.

15 Catechism, $\S \S 161,1026,2016$.
} 
can enter heaven, he may need to make atonement for temporal punishment not paid on earth. ${ }^{16}$ D. G. Bloesch calls this Christian Mystical Model of Salvation. ${ }^{17}$

Space does not allow us to trace the development of ordo salutis in Lutheran theology, but we have to note that in the late Seventeenth Century it was used to solve the following important issue. By imputing Christ's righteousness to believers God made them formally righteous. 'It is thus an open question how the content of this divine verdict becomes a reality for believers themselves.' ${ }^{18}$ Hollaz and J. W. Baier differed in their ordo salutis as Hollaz focused wholly on applying salvation by God and Baier on applying salvation to us. But for both of them it is clear that 'the faith of the regenerate counts as an $o b$ ject and not merely the result of the divine sentence of justification'. ${ }^{19}$

Thus the issue of ordo remained, whether the righteousness of faith preceded or succeeded the declaration of righteousness.

Before a more detailed examination of the Reformed doctrine, we need at least a glimpse of the Arminian doctrine. Initial salvation is received as a free gift. 'Salvation is offered only as God's free gift to men. ${ }^{20}$ However free will and human responsibilities are the deciding factors of final salvation. ${ }^{21}$ Faith serves not only to justify but also to regenerate. According to $\mathrm{R}$. Shank 'in spiritual birth, the subject must have a prior knowledge of the Gospel and must give consent... He becomes a partaker of the life and nature of Him who begets - a participant, by faith, in the eternal life of God in Christ.' 22 The grace of regeneration supplies the grace of perseverance but this grace may be forfeited. In Corner's words, 'after initial salvation a Christian's entrance into the kingdom of God can be negated'. ${ }^{23}$

A. Hoekema called the Wesleyan and some Pentecostal models three-stage soteriology: (1) conversion-justification, (2) sanctification-

16 Catechism, $\S \S 1030,1682$. For a more detailed critical evaluation see J. G. McCarthy, The Gospel according to Rome (Eugene: Harvest House, 1995): esp. 21121.

17 D. G. Bloesch, Jesus Christ: Saviour \& Lord (Leicester: IVP, 1997): 189-90.

18 W. Pannenberg, Systematic Theology (3 vols.; Edinburgh: T\&T Clark, 1993-1998): 3.228 .

19 Pannenberg, Systematic Theology, 3.229.

20 R. L. Shank, Life in the Son (Minneapolis: Bethanz House Publisher, 1989): 13.

21 D. D. Corner, Believer's Conditional Security (Washington: Evangelical Outreach, 1997): 76.

22 Shank, Life in the Son, 90-91.

23 Corner, Believer's Conditional Security, 93. 
Christian perfection and (3) Holy Spirit baptism (with Pentecostals) or perfection (with Wesleyans). ${ }^{24}$ Such evaluation at least in the case of Wesleyan soteriology seems to be oversimplified. Wesley scholar K. J. Collins discerns in Wesley the via salutis with 'two distinct foci: the elements that pertain to justification, and those that pertain to entire sanctification'. ${ }^{25} \mathrm{He}$ demonstrates the structural relationship between them in the following chart: ${ }^{26}$

Justification

$\begin{array}{ll}\begin{array}{l}\text { Similarity } \\ \text { Difference }\end{array} & \begin{array}{l}\text { Accusation } \\ \text { Actual sin }\end{array} \\ \text { Similarity } & \text { Self-knowledge } \\ \text { Difference } & \text { Legal repentance }\end{array}$

\section{Entire sanctification}

Accusation

Inbred sin

\section{Repentance}

Self-knowledge

Evangelical repentance

\section{Works meet for repentance}

$\begin{array}{lll}\begin{array}{l}\text { Similarity } \\ \text { Difference }\end{array} & \begin{array}{l}\text { Conditionally necessary } \\ \text { Not good (strictly speaking) }\end{array} & \begin{array}{l}\text { Conditionally necessary } \\ \text { Good (sanctifying grace) }\end{array} \\ \text { Similarity } & \begin{array}{l}\text { Unconditionally } \\ \text { Necessary }\end{array} & \begin{array}{l}\text { Unconditionally (exactly as) } \\ \text { Necessary }\end{array} \\ \text { Difference } & \begin{array}{l}\text { A sure trust that Christ } \\ \text { 'died for my sins' }\end{array} & \begin{array}{l}\text { A sure trust that Christ is 'able } \\ \text { to save from all the sin which } \\ \text { remains' }\end{array}\end{array}$

\section{Temporal dimensions}

\begin{tabular}{|c|c|c|}
\hline Similarity & Gradual/instantaneous & Gradual/instantaneous \\
\hline Difference & Image of birth & Image of death \\
\hline \multicolumn{3}{|c|}{ The witness of the Spirit } \\
\hline Similarity & Direct witness & Direct witness (clearly as \\
\hline Difference & Sins forgiven & Sin "taken away" \\
\hline
\end{tabular}

24 A. A. Hoekema, Saved by Grace (Grand Rapids: Eerdmans, 1989): 18 and Bloesch, Jesus Christ, 193-194.

25 K. J. Collins, The Scripture Way of Salvation: The Heart of John Wesley's Theology (Nashville: Abingdon, 1997): 188.

26 Collins, Scripture Way, 188-189. 
This chart reflects the fact that Wesley employed the same terms to describe two different processes of salvation (justification and entire sanctification). The level of similarities helps us to understand what he meant by these terms and the level of differences helps us to see the soteriological change in believers. That points to Wesley's emphasis on spiritual growth in his goal-oriented theology. Collins concludes:

Parallelism, in contrast, broadly understood, is able to account for both the journey of salvation as well as the key points along the way; it can properly integrate the processive nature of the via salutis as well as its instantaneous elements; and it can underscore not only the significance of development and maturation, but also the cruciality of realization in a manner that other models, or the lack of a model, cannot. ${ }^{27}$

This we believe is Wesley's important contribution to an ecumenical soteriology. ${ }^{28}$

A charismatic Wesleyan scholar, R. S. Taylor, discerns two basic levels on the Christian pilgrimage:

In the Christian life there is a usual sequence of spiritual events and experiences. They may be said to begin with awakening, conviction, and repentance, climaxing in justification as the first crucial change. Then follow growth and discovery, obstacles and discouragements. ... But as hunger deepens there will develop a major crisis of confrontation with God, issuing in total surrender and the infilling with the Holy Spirit. This will be the second major change. After this will come released power and freedom, more rapid progress... There may even be minor regressions. But on the whole, the holy walk will be forward and upward, until the gates of the City swing outward, then close behind us forever. ${ }^{29}$

A type of three-stage process of salvation is also the concept of the 'carnal Christian'. It has been based on an interpretation of 1 Corinthians 2:14 and proposed by the Scofield Reference Bible, Campus Crusade for Christ, ${ }^{30}$ J. R. McQuilkin, ${ }^{31}$ and by proponents of

27 Collins, Scripture Way, 190.

28 Collins evaluates the points of contact with other mainline soteriologies in Scripture Way, 205-207.

29 R. S. Taylor, Exploring Christian Holiness (vol. 3; Kansas City: Beacon Hill, 1985): 145-46. He then goes on to develop these principles until p. 151.

30 Lay Trainee's Manual (San Bernardino: Campus Crusade for Christ, 1968): esp. $155-57$

31 J. R. McQuilkin, 'The Keswick Perspective' in Five Views on Sanctification, ed. M. Dieter et al. (Grand Rapids: Zondervan, 1987): 149-83. Demarest makes the distinction between the Wesleyan and the Keswick view by describing the former as 'eradicationist' and the latter as 'counterreactionist' in relation to sin. See B. Demarest, The Cross and Salvation (Wheaton: Crossway, 1997): 397. 
the so-called Partaker or 'Once Saved, Always Saved' view of salvation. The most elaborate treatment of this subject is to be found in J. C. Dillow who defines the carnal Christian as 'a Christian who is knowingly disobedient to Christ for a period of time... However, if they were truly born again in Christ, they will go to heaven when they die.' ${ }^{32}$ Thus they are suggesting at least three stages: (1) non-Christians who are spiritually dead, (2) carnal Christians who may persist in sin to the end of life, and (3) spiritual Christians who persevere in faith. He correctly recognises that there is 'a continuum of sin in the heart' of Christians. 'The only difference between the most sincere saint and the most carnal one is a matter of degree. ${ }^{33}$ However there must be more to it since, even according to Dillow, the carnal Christian is 'knowingly disobedient' and 'apparently persisting in sin'. ${ }^{34}$

We believe that this view has been successfully refuted by $A$. Hoekema, ${ }^{35}$ D. A. Carson, ${ }^{36}$ G. D. Fee, ${ }^{37}$ and going to the extreme, D. D. Corner. ${ }^{38}$ "The "carnality" of the Corinthians, therefore, is their spiritual immaturity - an immaturity which they should outgrow. It does not imply that in the lives of these Christians self is exclusively on the throne, or that they are totally enslaved by the flesh. The "carnality," in other words, is a behavior problem. ${ }^{39}$ Kohlbrugge reflecting on Romans 7 said, "The believer will never invalidate the confession of Paul: "I am carnal" - "carnal in body and soul, in mind and will, in all my senses and members. My total existence is sin, but through faith I am partaker of the full righteousness and holiness of Christ." ${ }^{40}$ Demarest also identifies no 'sharp dividing line' between a carnal and a spiritual Christian. 'Every Christian is characterized by a measure of holiness and truth on one hand, and by a dose of carnality and worldliness on the other... The terms "spiritual" and "carnal" apply to every Christian, although not in equal measure or in the same res-

32 J. C. Dillow, Reign of the Servant Kings: A Study of Eternal Security and the Final Significance of Man (Miami Springs: Schoettle, 1992): 311-31, esp. 311.

33 Dillow, Reign, 313.

34 Dillow, Reign, 311.

35 Hoekema, Saved by Grace, 20-27.

36 D. A. Carson, 'Reflections on Christian Assurance', Westminster Theological Journal 54 (1992): 1-29, esp. 7-10.

37 G. D. Fee, The First Epistle to the Corinthians (Grand Rapids: Eerdmans, 1991): 116-17.

38 Corner, Believer's Conditional Security, 153-66.

39 Hoekema, Saved by Grace, 25.

40 G. C. Berkouwer, Faith and Sanctification (Grand Rapids: Eerdmans, 1969): 104. 
pects.' ${ }^{41}$ Thus we must not minimise the fact that 1 Corinthians 3 contrasts carnal and spiritual believers, but it is a distinction of degree and not of kind.

Finally, even within Reformed theology we find a very diverse understanding of ordo salutis. We shall not strictly follow the historical development of the doctrine rather than discern the different approaches to it. R. A. Muller defines it as 'a term applied to the temporal order of causes and effects through which the salvation of the sinner is accomplished' and recognises that 'the actual arrangement of the several elements of the ordo, i.e. calling, and so on, varies from system to system'. ${ }^{42}$ J. Murray also discerns a chronological order along with causation and explanation. From John 3:3, 5 he understands that regeneration is prior to seeing or entering into the kingdom of God. ${ }^{43}$ Based on 1 John 3:9 he affirms that regeneration is prior to liberation from sin. According to John 1:12 'adoption presupposes faith, and therefore faith is prior to adoption. So we should have to follow the order, faith and adoption.' ${ }^{44}$ Ephesians 1:13 suggests that hearing and believing are prior to the sealing of the Spirit. Following the discussion of the main text of Romans 8:29-30, he arrives at the following order in the application of redemption:

calling | regeneration | conversion | justification | adoption | sanctification | perseverance $\mid$ glorification. ${ }^{45}$

O. Weber is not content with such a sequence and asks, 'What happened to the forensic justification if it appears in a chain with many other events? The eschatological character of justification is apparently lost. ${ }^{\prime 6} \mathrm{He}$ refuses to build a sequence in time to avoid the following danger in which the individual phases of the salvation process replace the previous ones. ${ }^{47}$ Pannenberg explicitly affirms, 'The formula of the

41 Demarest, Cross, 416.

42 Dictionary of Latin and Greek Theological Terms, ed. R. A. Muller (Grand Rapids: Baker, 1985): 215.

43 J. Murray, Redemption Accomplished and Applied (Edinburgh: Banner of Truth, 1961): 80.

44 Murray, Redemption, 81.

45 Murray, Redemption, 87. Instead of conversion he prefers faith and repentance. We have arranged the elements in such a discrete line because contrary to others he emphasises that 'we must not think of it as one simple and indivisible act' (p. 80). A. T. B. McGowan also sees it as a chronological order, in The New Birth (Fearn: Christian Focus, 1996): 152.

46 Weber, Grundlagen, 2.379.

47 Weber, Grundlagen, 2.379. 
righteousness of faith clings to the fact that the Christian life as a whole is a life in faith.' ${ }^{48}$ A similar approach is taken by Burkhardt. He understands justification and sanctification as parallel terms. 'Sanctification is subject of faith, too. Justification and sanctification enter in the same time... The one who is converted or regenerated is also justified and sanctified.' 49

L. Berkhof, M. J. Erickson and G. R. Lewis with B. Demarest prefer to discern a logical order of salvation. Berkhof recognises that the Bible does not give us a complete order of salvation but 'it offers us a sufficient basis for such an order' ${ }^{50}$ However we need to be aware that some of the terms we operate with are not always used in the same sense.

We should carefully distinguish between the judicial and the recreative acts of God, the former (as justification) altering the state, and the latter (as regeneration, conversion), the condition of the sinner; - - between the work of the Holy Spirit in the subconscious (regeneration), and that in the conscious life (conversion); - between that which pertains to the putting away of the old man (repentance, crucifying of the old man), and that which constitutes the putting on of the new man (regeneration and in part sanctification); - and between the beginning of the application of the work of redemption (in regeneration and conversion proper), and the continuation of it (in daily conversion and sanctification). ${ }^{51}$

Thus logically justification is prior to the remaining work of grace. '[T]he work of God's grace in the subconscious, precedes that in the conscious life, so that regeneration precedes conversion.' ${ }^{52}$

Erickson and Lewis with Demarest on the other hand argue for the logical precedence of conversion before regeneration without succumbing to Arminianism. Distinguishing between effectual calling and regeneration, Erickson affirms that special calling is simply an intensive and effectual working by the Holy Spirit. It is not the complete transformation which constitutes regeneration, but it does render the conversion of the individual both possible and certain. ${ }^{53}$ Thus a logical 'listing of the ordo looks like this: election, verbal calling, effectual calling, belief of the Gospel, repentance from sin, trust in the living

48 Pannenberg, Systematic Theology, 3.236.

49 H. Burkhardt, Einführung in die Ethik (Giessen: Brunnen, 1996): 141.

50 L. Berkhof, Systematic Theology (Edinburgh: Banner of Truth, 1979): 416.

51 Berkhof, Systematic Theology, 419.

52 Berkhof, Systematic Theology, 419.

53 M. J. Erickson, Christian Theology (Grand Rapids: Baker, 1998): 933. 
Christ, regeneration, justification, reconciliation, sanctification, perseverance and glorification' ${ }^{54}$ However as P. Masters shows in his survey of Reformed teaching on regeneration, this difference may be explained if one recognises that Puritan and continental Calvinists distinguished between the unconscious initial regeneration and the new birth as a conscious receiving of the new nature. ${ }^{55}$

Rather than a chronological or logical order, L. R. Reymond derived from 'the skeletal framework of the Ordo in Romans 8:29-30'56 a sequential order of divine acts and divine-human activities. He arranged them in the following columns reflecting 'the logical (or causal) connection between the several aspects': ${ }^{57}$

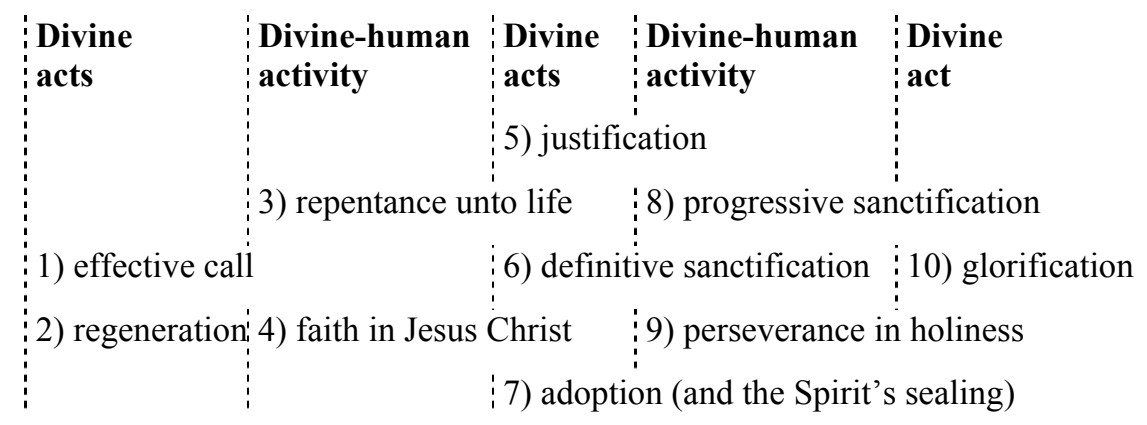

We find yet another approach in $\mathrm{K}$. Barth and he called it the teleological order. He tries to shift the basic meaning of the term ordo (before and after). Justification and sanctification for him are not successive steps. 'The simul of the one redemptive act of God in Jesus Christ cannot be split up into a temporal sequence, and in this way psychologized. ${ }^{58}$ However he also needs an order. That which comes

54 Gordon R. Lewis and Bruce A. Demarest, Integrative Theology (3 vols.; Grand Rapids: Zondervan, 1994): 3.57. See also their discussion of the movements in our legal standing, in our unconscious and our conscious experiences on pp. 58, 82-84 and 97-107.

55 P. Masters, 'Regeneration: Elongated or All-at-once?' in Sword \& Trowel 2 (1996): 7-14.

56 R. L. Reymond, A New Systematic Theology of the Christian Faith (Nashville: Thomas Nelson, 1998): 704-6.

57 Reymond, New Systematic Theology, 711. The way the publisher printed the first two divine acts suggests that regeneration is a divine-human activity which clearly is not what the author intended.

58 K. Barth, Church Dogmatics (4 vols.; Edinburgh: T\&T Clark, 1963-1977): IV.2.507, cf. 505: 'Justification and sanctification must be distinguished, but they cannot be divided or separated.' 
first in execution (justification before sanctification) comes second in purpose (justification as a condition to sanctification). ${ }^{59}$

\section{Ordo Salutis Justified}

We have provided the above survey not so much to make a critical evaluation of each individual approach as to show the complexity of the issue. We have noticed a great diversity even within the Reformed soteriology. It still does not seem to be much clearer whether regeneration or effectual calling comes first; whether conversion is once for all or daily; even within conversion how faith is related to repentance, or how sanctification, perseverance and glorification are connected. Hence it may be legitimate to question whether in such circumstances it is still appropriate to affirm any ordo salutis at all. In the following we shall first deal negatively with the objections to the very idea of an ordo salutis and then positively with the justification of the attempts to present a consistent and meaningful order of salvation.

One of the most serious Reformed critics of the systematisation of the ordo salutis is G. C. Berkouwer. He complains about it as 'evidence of too much concern with the regenerated or believing man in the various stadia of his life and not enough interest in the riches of the objective divine salvation'. ${ }^{60} \mathrm{He}$ sees that criticism of the way of salvation in the past

was motivated by a fear that the subjective life of faith be made an independent area of study... It was further said that the theological overattentiveness to the way of salvation meant that salvation was thought of as human activity, and that the basic Reformation acknowledgement of salvation as grounded exclusively in God's grace was therewith abandoned. ${ }^{61}$

Berkouwer acknowledges that the motive behind the ordo salutis was the maintenance of the sovereignty of God's grace. However, we must still give some credence to such criticism today since even

59 Weber, Grundlagen, 2.381. Barth follows here the structure of the third book of Calvin's Institutes. However Weber's critical comparison shows a significant difference of meaning and conditions of the process. See pp. 382-83.

60 G. C. Berkouwer, Faith and Justification (Grand Rapids: Eerdmans, 1954): 25. Similar criticism is adopted by G. J. Spykman, Reformational Theology: A New Paradigm for Doing Dogmatics (Grand Rapids: Eerdmans, 1992): 481-83.

61 Berkouwer, Faith and Justification, 26. 
psychological investigations such as those of the Journal for the Scientific Study of Religion, more than theological works, are given to the study of conversion and faith. L. R. Rambo's book is one of the most elaborate studies concentrating on personal, cultural, social, and religious implications of conversion. ${ }^{62}$ Undeniably psychology and sociology play their important parts in conversion but the purpose of the ordo salutis is to unfold the divine work in human beings while maintaining God's sovereignty and to set this outworking forth in an orderly way.

Berkouwer further complains that 'the order often prevailed over the salvation' and 'the simple biblical perspective of the way of salvation is often lost in the practice. This also helps to account for the endless variations in the ordo salutis that appear in the history of Reformed theology.' ${ }^{63} \mathrm{He}$ approved Calvin's treatment of the subject in the third book of Institutes: 'Though one does not find an ordo salutis in Calvin, in the sense of its later development, there is nonetheless an order, perhaps better called an orderliness, which is determined by salvation in Christ. ${ }^{64}$ Setting the key biblical reference of Romans 8:29-30 alongside other texts like 1 Corinthians 1:30; 6:11 and Titus $3: 5$, Berkouwer suggests that Paul does not have a sequence in mind and concludes with Seeberg, 'Only the richness, not the order, of the way of grace comes to expression. ${ }^{65} \mathrm{He}$ proposes to replace the ordo salutis by a more biblical concept of the via salutis. ${ }^{66}$

In his discussion of the doctrine of perseverance, H. Berkhof included a paragraph of critical evaluation of ordo salutis. He observes that

on the basis of Rom. 8:29f. (sometimes Acts 26:17f. is cited as well), attempts were made to introduce a kind of sequence in the renewal process... That easily led to "categorization," thereby turning the way of salvation into a psychological process. Already the aorists used by Paul, even for designating future "phases" (so: edoxasen), prove that that was not what he had in mind, but that his concern was the unity of the

62 L. R. Rambo, Understanding Religious Conversion (New Haven: Yale University, 1993).

63 Berkouwer, Faith and Justification, 27.

64 Berkouwer, Faith and Justification, 29.

65 Berkouwer, Faith and Justification, 31.

66 Berkouwer, Faith and Justification, 35-36. 
aspects in the process of renewal as these exist in God's eternal gracious purpose for man. ${ }^{67}$

However he acknowledges that such a process has at least a logical before and after.

To justify an ordo salutis requires us to take notice of the preceding criticisms and above all to glean from biblical soteriology. We intend to do the latter using the seminal work of R. B. Gaffin, Jr. ${ }^{68}$ Developing the conclusions of G. Vos and H. Ridderbos, he is critical of too much preoccupation with the doctrine of justification by faith and other aspects of the ordo salutis in Paul's soteriology and with the doctrine of atonement in Paul's Christology. Gaffin focuses on the soteric efficiency of the resurrection for Paul's soteriology. ${ }^{69}$ All three scholars come to the following conclusion:

The center of Paul's teaching is not found in the doctrine of justification by faith or any other aspect of the ordo salutis. Rather, his primary interest is seen to be in the historia salutis as that history has reached its eschatological realization in the death and especially the resurrection of Christ. ${ }^{70}$

However, we believe that Gaffin's insights will correct and inform the traditional understanding of ordo salutis rather than abolish such a doctrine.

Concluding his expositions of 1 Corinthians 15:45; 2 Corinthians 3:17; Romans 1:3, 4; Acts 13:33, Gaffin shows that 'the significance of the resurrection is more than noetic, it involves more than an unveiling of the efficacy of the cross'. ${ }^{71}$ If Christ died being made sin $(2$ Cor. 5:21), he had to be redeemed by being raised. Thus for Paul 'the accomplishment of redemption is only first definitively realized in the application to Christ himself (by the Father through the Spirit) at the resurrection of the benefits purchased by his own obedience unto death'. ${ }^{72}$ That has direct implications for the application of redemption to believers.

67 Berkhof, Christian Faith, 482.

68 R. B. Gaffin, Resurrection and Redemption: A Study in Paul's Soteriology (Phillipsburg: Presbyterian and Reformed, 1987).

69 Gaffin, Resurrection, 11-16.

70 Gaffin, Resurrection, 13.

71 Gaffin, Resurrection, 115.

72 Gaffin, Resurrection, 117. 
First is the metaphor of adoption. According to Romans 1:4 Jesus

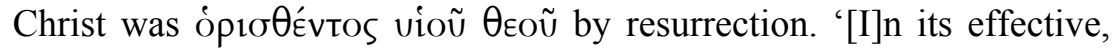
transforming character the resurrection has a declaratory significance... the resurrection of Jesus is his adoption (as the second Adam). ${ }^{73} \mathrm{He}$ then links this with Romans 8:23 which describes believers waiting 'eagerly for our adoption as sons, the redemption of our bodies', that is resurrection. 'The inherently forensic concept of adoption fulfils itself in the somatic transformation of resurrection, so that in view of the (Adamic) unity of the resurrection of Christ and believers, what is true of the latter holds for the former.' 74

Gaffin also interprets 1 Timothy 3:16, Romans $4: 25$ and 1 Corinthians 15:17 in line with that. He believes them to 'show that the enlivening of Christ is judicially declarative not only, as we saw earlier, in connection with his messianic status as son, his adoption, but also with respect to his (adamic) status as righteous. The constitutive, transforming action of resurrection is specifically forensic in character. It is Christ's justification.' 75

Moving on to sanctification, Gaffin does not employ the term in its customary sense of progressive ethical renewal either. He sees Paul referring to it as 'to a definitive act occurring at the inception of the Christian life (Acts 20:32; 26:18; I Cor. 1:2; 6:11; Eph. 5:25; II Tim. 2:21; I Thess. 4:7; II Thess. 2:13)' ${ }^{76}$ understanding oó $\rho \xi$ as specifying 'in an all-inclusive fashion the distinguishing character of the old aeon, the fallen preeschatological world order. Accordingly, sanctification embraces all that pertains to deliverance from the power of the "flesh" understood in this comprehensive, aeonic sense.' 77 Consequently Christ's resurrection is Christ's sanctification. According to Romans 6:1-11 the same applies to believers.

The same principle can be seen in the concept of glorification. 'Passages like I Corinthians 15:42ff. and II Corinthians 3:17f.; 4:4-6, as well as the genetic association of glory with the Spirit, show that the pneumatic transformation experienced at Christ's resurrection involves

73 Gaffin, Resurrection, 118. He finds the same pattern of thought in Acts 13:33 and Phil. 2:6-11.

74 Gaffin, Resurrection, 119.

75 Gaffin, Resurrection, 124.

76 Gaffin, Resurrection, 124.

77 Gaffin, Resurrection, 125-26. 
the final and definitive investiture of his person with glory.' ${ }^{78}$ As God's goal for the elect is 'to be conformed to the likeness of his Son', it will be realised by calling, justification and glorification. ${ }^{79}$ That, according to 1 Corinthians 15:49, happens at the resurrection.

Adoption, justification, sanctification and glorification are used by Paul with dual purposes: (1) to explain the meaning of Christ's resurrection and (2) to explain the meaning of the Christian's salvation. The former determines the latter. This understanding gives Gaffin a powerful argument for seeing adoption, justification, sanctification and glorification not as separate, distinct acts, but each as describing a different aspect of the one act of being raised from the dead ${ }^{80}$ That challenges the traditional Reformed ordo salutis which either chronologically or logically places regeneration before justification, adoption and sanctification, and glorification after them.

[B]eing raised with Christ has the same significance for believers that his resurrection has for Christ... It means that he [the believer] has been justified, adopted, sanctified, and glorified with Christ, better, that he has been united with the Christ, who is justified, adopted, sanctified, and glorified, and so by virtue of this (existential) union shares these benefits. $^{81}$

More importantly, the concept of the believer's incorporation with the resurrected Christ helps Gaffin to discharge the tension perceived in Paul's soteriology — between the forensic and the ethical.

The results of Gaffin's study point to the need to replace the traditional ordo salutis with the Pauline concept of existential incorporation with the life-giving Spirit of the resurrected Christ. That is exactly what $\mathrm{S}$. B. Ferguson proposed:

Every facet of the application of Christ's work ought to be related to the way in which the Spirit unites us to Christ himself, and viewed as directly issuing from personal fellowship with him. The dominant motif and architectonic principle of the order of salvation should therefore be union with Christ in the Spirit. ${ }^{82}$

If we take ordo to mean a chronological sequence of distinct soteric acts, or sequences of divine acts and divine-human actions, or logical

78 Gaffin, Resurrection, 126.

79 Rom. 8:29-30.

80 Gaffin, Resurrection, 127, 131, 136.

81 Gaffin, Resurrection, 129.

82 S. B. Ferguson, Holy Spirit (Leicester: IVP, 1996): 100. 
causes and effects, or divine teleological purposes and means to achieve them, then we should follow Gaffin's direction. However, even he recognises the calling of God as the origin of the believer's faith. ${ }^{83}$ Further, even if the already realised union with the risen Christ (the resurrection of the believer's inner man) is irreversible because of his resurrection, the believer's bodily resurrection is still future. This eschatological tension also has to be appreciated in soteriology by seeing salvation not only as a state but also as a process which takes more than the time between the resurrection realised and the resurrection future. It takes his perseverance.

Even such a critic of ordo salutis as Berkouwer recognises:

Sometimes generations of Christians have lost the joy of the gospel by having gone amiss on the way of salvation. This is why it is perpetually necessary for the Church to reflect on the ordo salutis, or, as we think better to say on the way of salvation. The purpose of her reflection is not to refine and praise the logical systematization. It is to cut off every way in which Christ is not confessed exclusively as the Way. This defines the character of the entire doctrine of soteriology. ${ }^{84}$

Thus we believe that rather than abandon the Reformed doctrine of ordo salutis, we need to redefine it, taking into account both the pitfalls and the benefits of the development of this doctrine.

\section{Ordo Salutis Redefined}

Recognising the great variety, but having justified the need for systematisation of the ordo or via salutis, we believe it is important to make certain qualifications. In that way the ground will be prepared for our own definition of ordo salutis. A helpful summary of these qualifications may be found in B. Demarest's seminal work The Cross and Salvation (see fn. 31 above).

(1) The order of salvation includes things that God does... as well as things that humans do... (2) The ordo must be viewed as a logical as well as a chronological relation... (3) Certain aspects of the scheme of salvation are not discrete events but realities that pervade the entire Christian life... (4) ...aspects of the salvation experience are interactive... Hence the order of salvation must not be viewed simplistically as a

83 Gaffin, Resurrection, 142.

84 Berkouwer, Faith and Justification, 36. 
linear sequence of chronological occurrences. And finally (5) every aspect of salvation profoundly focuses on Christ. ${ }^{85}$

The development of our thesis will make it obvious that we do not agree with every assertion of these qualifications, nevertheless the qualifications themselves are to be affirmed as Demarest stated them.

God applies his grace to the individual in a unitary process. A. A. Hoekema therefore prefers to speak about via rather than ordo salutis: 'We should think, then, not of an order of salvation with successive steps or stages, but rather of a marvellous work of God's grace-a way of salvation-within which we may distinguish various aspects.' ${ }^{26}$ Berkouwer is right in observing that, " $[\mathrm{t}]$ he theological schematization of the order of salvation, thus, has no significance by itself. The order is relevant only in that it aids us to appreciate the fullness of divine salvation. ${ }^{87}$

Since neither chronological nor logical nor sequential nor teleological orders of salvation are satisfactory descriptions of the applications of divine grace to the individual, we prefer to take side with those who emphasise the orderliness of the process of salvation. R. J. Rushdoony's assertion points to the right purpose in that

the Ordo Salutis is not a matter for dissection but proclamation. It is our God who saves us. Every aspect of our salvation, from eternity to eternity and all through time, is of His ordination and predestination, and it is a glorious, seamless garment. The Ordo Salutis sets forth our salvation, wealth, power, and security in Jesus Christ. It is not a matter for disputation but exultation. ${ }^{88}$

Our dissection or disputation is to make our proclamation and exultation more orderly. Thus there is no antithesis between the gospel proclamation and ordo salutis. 'For the way we present the gospel invariably expresses an implicit understanding of the ordo salutis.' 89 Since our definition of ordo salutis is based on A. Hoekema's description, it will be helpful to start with him as shown in the following Fig. $1 .{ }^{90}$ A few critical comments are necessary here.

85 Demarest, Cross, 43. Hoekema also distinguishes judicial and moral aspects, and observes that most of the suggested orders are not complete. See Hoekema, Saved by Grace, 13-14.

86 Hoekema, Saved by Grace, 15.

87 Berkouwer, Faith and Justification, 27.

88 R. J. Rushdoony, Systematic Theology (vol. 1; Vallecito: Ross House, 1994): 1.505.

89 Ferguson, Holy Spirit, 97.

90 Hoekema, Saved by Grace, 16. 
Hoekema has left out 'calling' from his diagram as shall we since, strictly speaking, an effectual call immediately precedes the actualisation of salvation. From the human perspective it is regeneration that makes the general call an effectual call. On the other hand, Hoekema also left out glorification saying that 'this is an aspect of eschatology'. ${ }^{91}$ By that explanation he gives the impression that the other aspects like regeneration, conversion, justification, sanctification and perseverance were not eschatological in their nature. We believe that our discussion of Gaffin's study in Paul's soteriology ${ }^{92}$ and the whole thrust of Moltmann's and Pannenberg's theology sufficiently prove that every aspect of salvation is eschatological.

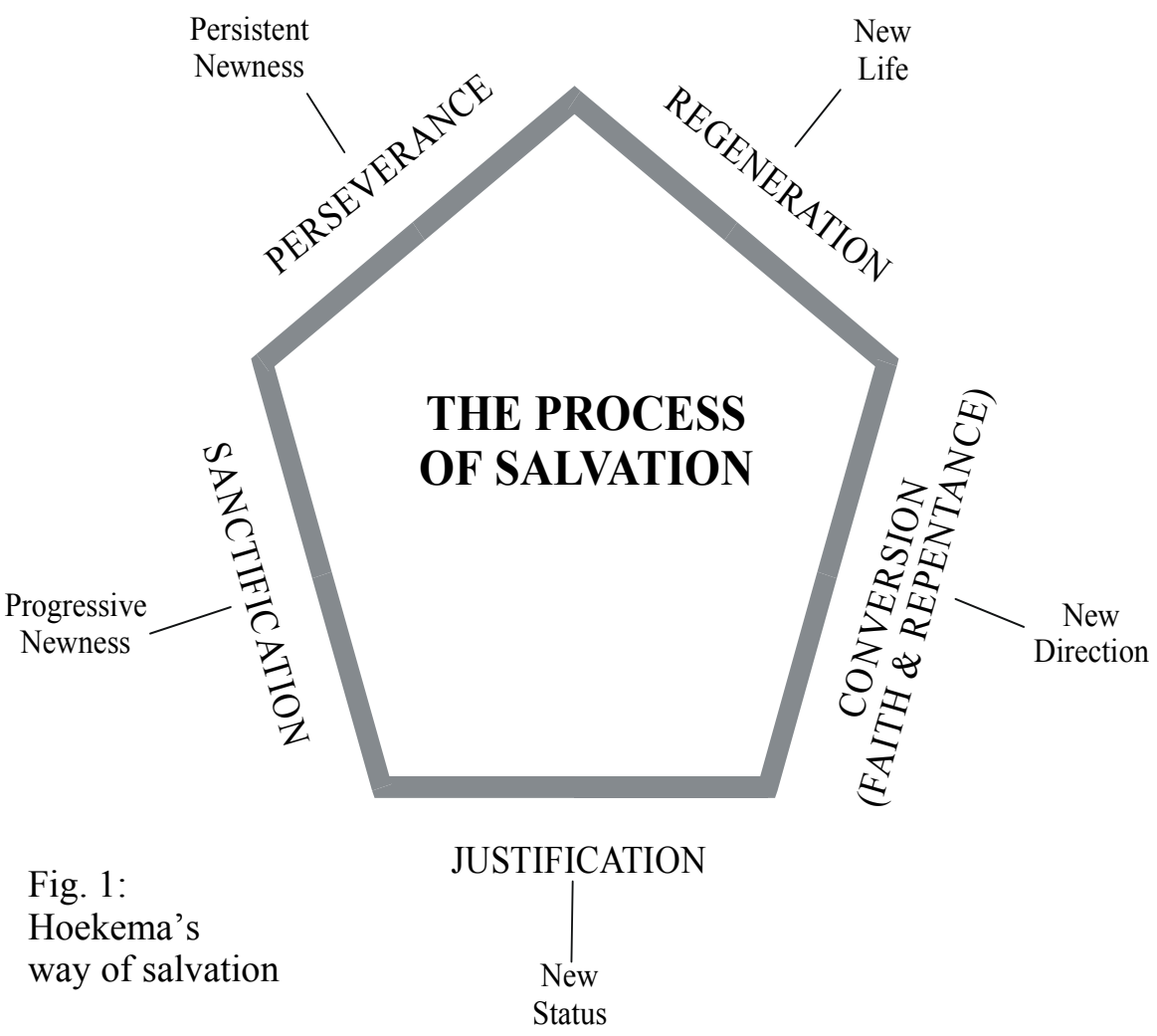

91 Hoekema, Saved by Grace, 17.

92 See Gaffin, Resurrection, 137-38: 'The traditional ordo salutis lacks the exclusively eschatological air which pervades the entire Pauline soteriology. Or, to put it the other way around, the former point of view amounts to a definite deeschatologization of Paul's outlook. For him soteriology is eschatology.' 
The process of glorification starts at the beginning of spiritual life and not only in its consummation. Our salvation takes place in an inaugurated eschatology. Another weakness of Hoekema's diagram is that it does not do justice to what are the definitive and what are the progressive aspects of salvation. He needed to emphasise that 'sanctification is here understood in its progressive sense', although he knows that 'there is a sense in which sanctification is definitive or instantaneous' ${ }^{93}$ Which are the other aspects then? Thus our diagram of the beginning of the spiritual life is reflected in Figure 2.

Fig. 2:

Beginning of spiritual life

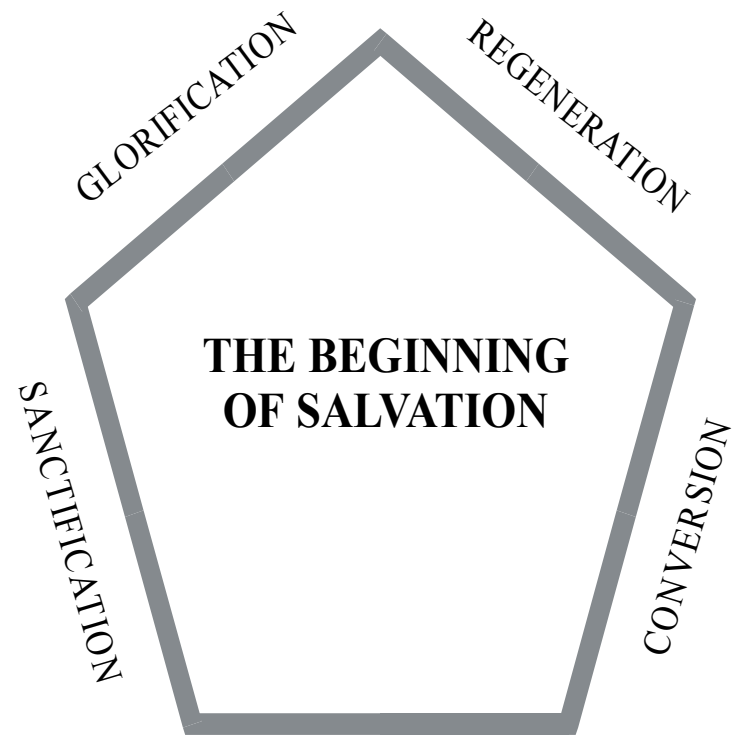

JUSTIFICATION

We wish to affirm that all these aspects of salvation are definitive rather than progressive. Each of them describes one facet of divine act or a divine-human action by which the Holy Spirit applies salvation to the individual believer. It is irrelevant trying to establish which of these aspects is preceding and which is succeeding. However, none of these aspects is to be subsumed in any other. In systematic theology a doctrine may develop a relatively independent meaning from its biblical usage. The doctrines of justification and sanctification are classical examples of this fact. From the time of Augustine to Melanchthon justification was generally understood as both imputed

93 See Gaffin, Resurrection, 17. 
and imparted righteousness. Thus justification included sanctification. On the other hand, the Protestant doctrine of sanctification especially is predominantly understood in progressive terms which are not the same as the biblical usage. Hence Protestants have difficulty in resolving the relationship between justification and sanctification.

Before proceeding further at least a brief consideration of the biblical data is required here. Almost all theologians discussing ordo salutis base their conclusions on relevant biblical passages. ${ }^{94}$ That is necessary for any, and especially evangelical, theology; but because of space limitations we shall restrict ourselves only to Romans 8:29-30. This passage, according to R. L. Reymond, constitutes 'the skeletal framework of the Ordo' ${ }^{95}$ Thus calling, justification and glorification as divine acts form the skeleton and divine-human activities are the muscles of his completed ordo which is a sequence of divine acts and divine-human activities. J. Murray argues on the same basis for his chronological and logical order. ${ }^{96}$ Traditional ordo salutis takes the calling, justification and glorification as separate acts. However, in R. Gaffin's interpretation 'Paul views them not as distinct acts but as distinct aspects of a single act. ${ }^{97}$ Most traditional theologies ignore the

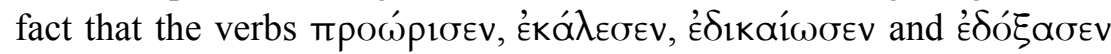
are in the same aorist tense. Even commentators like J. D. G. Dunn (with Mayer and Wilckens) argue, 'The aorist should not be required to yield the idea of a glorification already accomplished now, in baptism or wherever... it is the process seen from its end point and completion. ${ }^{98}$ D. Moo follows J. G. Volf in stressing that the links in this chain are firmly attached to one another, but maintains that the final verb in this chain denotes the action in the future, while the other actions are past although warning that 'we must, of course, be careful about making temporal categories too important in interpreting the

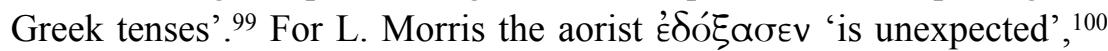
but only because of his traditional soteriological framework. However,

94 In addition to the extensively discussed study of R. Gaffin see also Demarest, Cross, esp. 40-42, Murray, Redemption, 80-85, Reymond, New Systematic Theology, 704-11.

95 Reymond, New Systematic Theology, 704-6.

96 Murray, Redemption, 82-84.

97 Gaffin, Resurrection, 138. See also his fn. 9.

98 J. D. G. Dunn, Romans 1-8 (Milton Keynes: Word, 1991): 485-86.

99 D. J. Moo, Romans (Grand Rapids: Eerdmans, 1996): 535-36.

100 L. Morris, The Epistle to the Romans (Downers Grove: IVP, 1988): 333. 
along with the following interpreters, we believe that a more simple and direct exposition is to be preferred. Chrysostom says that those he called, God justified by the regeneration of baptism and glorified by

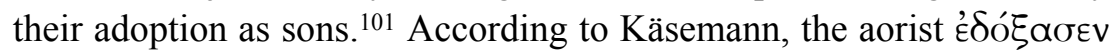
fits in relation to the Hellenistic context. ${ }^{102}$ Not only does the historical and religious context allow such an exposition but so does the immediate theological context of the passage. Gaffin argues, 'All soteric experience derives from solidarity in Christ's resurrection and involves existence in the new creation age, inaugurated by his resurrection. As Romans 8:30 reflects, the present as well as the future of the believer is conceived of eschatologically.' ${ }^{103}$ Thus he affirms, 'The organic inseparability of the future, bodily resurrection of believers from the realized aspect of being raised with Christ appears to involve the important structural implication that for Paul the justification, adoption, sanctification, and glorification of the believer are future as well as present.' ${ }^{104}$ G. D. Fee is certainly right in saying that in Romans 8:18-30 there is 'an eschatological tension between what we are and what we shall be'. ${ }^{105}$ However, since being glorified includes our identification with Christ, the eschatological tension is between the nature of glorification now-being identified with Christ in his sufferings - and in the future-when we will identify with Christ's resurrection glory. For these reasons we believe that it is biblically justified to redefine ordo salutis as we have done and illustrated in our Figure 2 above and Figure 3 below.

Our purpose in describing the ordo salutis is to appreciate the treasures that the one great work of redemption brings to believers. We have to do it in dynamic and not only in static terms. In most theologies some aspects are defined as definitive (justification) and others as progressive (sanctification and perseverance). We believe that it is more biblically accurate and theologically beneficial to take all the

101 Quoted in G. Bray, ed., Romans; Ancient Christian Commentary on Scripture VI (Downers Grove: IVP, 1998): 237. Similarly Theodoret of Cyrus, ibid.

102 E. Käsemann, An die Römer (HNT; Tübingen: J. C. B. Mohr, 1973), 236. Also in H. Schlier, Der Römerbrief, (HTKNT; Freiburg: Herder, 1977): 274: 'Sie (Glorie) hat uns also schon ergriffen und umfangen. Die gerufene und gerechtfertigte Existenz des Christen ist schon in den Zug der überschwenglichen Glorie getreten.'

103 Gaffin, Resurrection, 138.

104 Gaffin, Resurrection, 133.

105 G. D. Fee, God's Empowering Presence: The Holy Spirit in the Letters of Paul (Peabody: Hendrickson, 1994): 571. 
aforementioned aspects of ordo as definitive; all of them also have a progressive aspect. ${ }^{106}$ Before a natural man becomes a spiritual man, the most important thing is the beginning of his spiritual life-the inauguration of his salvation. This inauguration is defined by his new birth, conversion, justification, sanctification and glorification. However, from the moment of beginning the most important thing is not the beginning itself but the progress of the new life. After the inauguration of salvation, the most important concern is the progress toward the consummation of salvation. Thus the concern of believers is not to ascertain whether they are among the elect but whether there is progress in their spiritual lives. ${ }^{107}$ If 2 Peter 1:9 reminds the believer 'that he has been cleansed from his past sins', then the next verse turns his attention to the future: 'Therefore, my brothers, be all the more eager to make your calling and election sure.' They were not only called to repent of their past sins but also called to 'the eternal kingdom of our Lord and Saviour Jesus Christ' (v. 11). Thus the somewhat confusing slogan 'once saved, always saved', might be more appropriately replaced by 'once called, always called'. This progressive aspect of salvation will be the subject of the next section.

\section{Establishing the Doctrine of Perseverance within the Redefined Ordo Salutis}

A. Hoekema, as well as most of the other theologians, listed the perseverance of believers among the other aspects of salvation. We have not listed it among the aspects of the beginning of salvation which we have argued are all definitive aspects. Not only is perseverance progressive rather than definitive, but we want to argue that perseverance is not so much one aspect of salvation along with regeneration, conversion, justification, sanctification and glorification, as it is a comprehensive aspect reflecting the progressive nature of all the former aspects.

The regenerated person is to live a new life. ${ }^{108}$ The converted person is to be characterised negatively by mortificatio and positively by

106 Only justification is different in that we cannot be more justified than we have been, but our justification is to be followed by a life of righteousness and ended in public justification.

1071 Tim. 4:10-16, esp. v. 15.

108 Rom. 6:4, amplified in vv. 8-10. 
vivificatio. ${ }^{109}$ The justified person is to live in righteousness. ${ }^{110}$ The sanctified person is to live in holiness. ${ }^{111}$ Finally, those who are glorified are to be transformed into their Lord's likeness 'with everincreasing glory'. ${ }^{112}$

Since all these have a past, present and future aspect, it is not right to assign some to the past aspect of salvation (regeneration, conversion and justification), some to the present aspects (sanctification, and in most theologies perseverance ${ }^{113}$ ), and some to the future aspects of salvation (glorification). All of them belong to all three tenses of salvation. Neither are we justified in ascribing to some the definitive aspect and to some the progressive aspect. All five have a progressive aspect, but the terms regeneration, conversion, justification, sanctification and glorification are best understood as definitive divine acts or divine-human actions by which the spiritual life of the individual believer begins.

We wish at the same time to affirm the need for progress in the believer's spiritual life in all five aspects of his or her salvation. At the same time we ought to avoid the confusion caused by using the same term once as definitive and another time as progressive which has often been the case with the concept of sanctification.

Keeping all these as distinct aspects of salvation and keeping them in eschatological tension between already and not yet helps to avoid their fusion while maintaining their moral sanction for the believer. Not only the Roman Catholic theology but also the German realistic Protestant theology at the end of the Nineteenth Century that grew out of Pietism fell into this trap. J. T. Beck ${ }^{114}$ argues that justification is not to pronounce but to make righteous. ${ }^{115}$ This fusion of justification and

109 Rom. 8:13.

110 Rom. 6:18-19; Eph. 6:14; Phil. 3:9; 1 Tim. 6:11; 2 Tim. 2:22; 1 Pet. 2:24

1112 Cor. 7:1; 1 Thess. 3:13.

1122 Cor. 3:18. See Rushdoony's comment in his Systematic Theology, 1.554: 'When our Lord commands us to take up our cross and follow Him, He is not so much summoning us to a life of suffering as to put on Christ, to become members of Him, to follow Him wherever He leads us, and to be His witnesses, witnesses to His glory (Matt. 16:24-27; Mark 8:34; 10:21; Luke 9:23).

113 Erickson treats it with glorification as the completion of salvation, in Christian Theology, 985-1002.

114 Good evaluation of their theology is in J. P. Martin, The Last Judgment: In Protestant Theology from Orthodoxy to Ritschl (Grand Rapids: Eerdmans, 1963): 17086.

115 J. T. Beck, Vorlesungen über christliche Glaubenslehre (2 vols.; n.p.: Lindenmeyer, 1886-87): 2.603. 
sanctification allows him to emphasise the moral responsibility of the believer but at the same time leads him to confusion in the continuing justification after a being-made-righteous. We believe this confusion can be avoided by maintaining the link between the forensic character of justification and the last judgment. The moral requirement of both is met in the perseverance of the believer.

J. Moltmann points out an important difference between philosophical and biblical concepts of hope. Even the most positive philosophical concepts of hope retain strands of unease and uncertainty. The biblical concept of hope, on the other hand, is an expectation of a good future based on God's promise. 'Because hope is moulded by the way in which God is understood, and determined by a relationship with God, it is unambiguous.' 116 Whereas philosophical concepts of hope are extrapolations of the present into the future, Christian hope is the anticipation of the promised future itself. 'This future is already at work in the present in hope for the future of God.' 117 This anticipation of the promised future may be called perseverance in Christian hope.

Fig. 3:

Perseverance in salvation

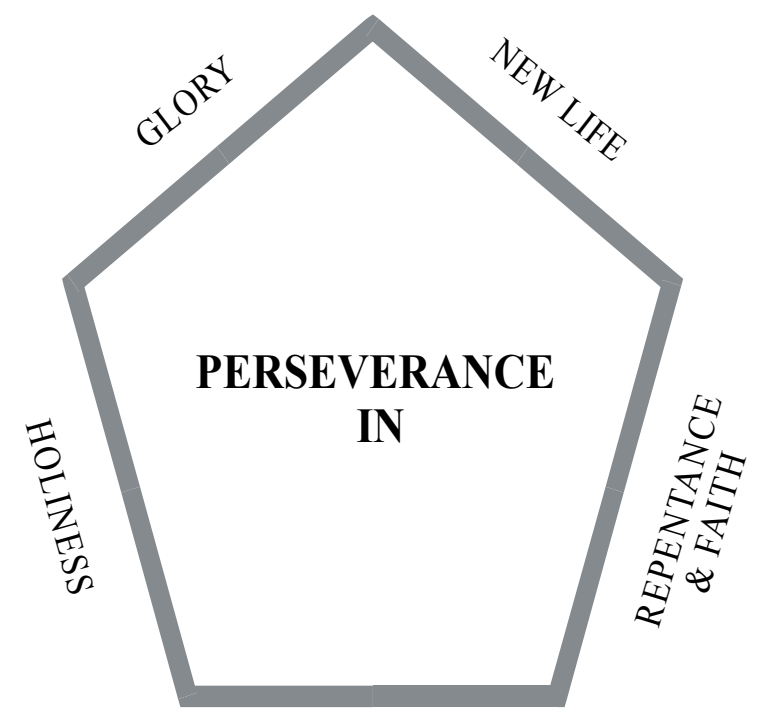

RIGHTEOUSNESS

We believe that the best single term with the potential to include the progressive emphasis of all five aspects of salvation is perseverance. It

116 J. Moltmann, 'Hope' in A New Dictionary of Christian Theology, ed. A. Richardson and J. Bowden (London: SCM, 1983): 271.

117 Moltmann, 'Hope', 271. 
fits very well with the following general definition of perseverance given by Collins English Dictionary: 'Continued steady belief or efforts, withstanding discouragement or difficulty'. ${ }^{118}$ The most general theological definitions of perseverance are that of J. Moltmann: 'the gift of persistence in faith and the preservation of believers to the end in temptation and persecution', ${ }^{119}$ or C. R. Meyer's 'continuance in the state of grace, and death in that state'. ${ }^{120}$ Figure 3 illustrates perseverance constituted in the progress of all five previous aspects of salvation.

The diagram makes clear that perseverance is not an aspect parallel to regeneration, conversion, justification and sanctification as depicted by Hoekema. It is rather to be understood as an inclusive term for the progress of all five aspects given in our diagram of the beginning of spiritual life.

After we have differentiated perseverance from regeneration, conversion, justification, sanctification and glorification, we need to do the same with another term often used in discussing the ordo salutis. It is the concept of union with Christ or unio mystica sive praesentia gratiae tantum. We have only briefly hinted at this concept above since it is not simply one aspect or phase of the ordo salutis. It underlies every aspect of salutis. L. Smedes argues that union with Christ is the centre and circumference of authentic Christian experience. ${ }^{121} \mathrm{~B}$. Demarest states, 'Amply attested in the NT, union with Christ proves to be a central verity, indeed a touchstone reality of the Christian life and experience.' ${ }^{22}$ We have already noted R. Gaffin's critical comments concerning the traditional ordo salutis but he very strongly argues in favour of Paul's concept of union with Christ, observing that 'despite a surface appearance to the contrary, Paul does not view justification, adoption, sanctification, and glorification of the believer as separate, distinct acts but as different facets or aspects of the one act of incorporation with the resurrected Christ' ${ }^{123}$

The concept of union with Christ is a somewhat enigmatic concept evoking many searching questions. Since most of them are outside the

118 Collins English Dictionary (Glasgow: HarperCollins, 1991).

119 J. Moltmann, 'Perseverance' in Richardson and Bowden, New Dictionary, 441-42.

120 C. R. Meyer, 'Perseverance, Final' in Encyclopedic Dictionary, ed. Meagler, 2739.

121 L. Smedes, Union with Christ (Grand Rapids: Eerdmans, 1983): xii.

122 Demarest, Cross, 313.

123 Gaffin, Resurrection, 130-31. 
scope of this article, we shall only be concerned with its relation within the ordo salutis in general and with our interpretation of perseverance in particular. ${ }^{124}$ Covenant theologians generally interpret union with Christ as embracing the whole scope of salvation from eternity past to eternity future. L. Berkhof describes it as having four phases: '1. The federal union of Christ with those whom the Father has given Him, in the counsel of redemption... 2. The union of life ideally established in the counsel of redemption... 3. The union of life objectively realized in Christ... 4. The union of life subjectively realized by the operation of the Holy Spirit.' ${ }^{125}$ Hoekema does not agree with Berkhof's description entirely but he also wants to

see this union as extending all the way from eternity to eternity. Union with Christ begins with God's pretemporal decision to save his people in and through Jesus Christ. This union, further, is based on the redemptive work for his people which Christ did in history. Finally, this union is actually established with God's people after they have been born, continues throughout their lives, and has as its goal their eternal glorification in the life to come. ${ }^{126}$

Union with Christ is not only covenantal or legal but also existential and experiential. In this sense ' $[\mathrm{u}]$ nion with Christ thus marks the end of the old existence and the beginning of the new'. ${ }^{127}$ Orthodox Lutheran and Reformed dogmatics speak about unio mystica 'because it rests on the mystery of grace and of the unsearchable mercy of God'. In relation to the ordo salutis they distinguish 'the initial unitio (q.v.), or uniting, of the unio mystica, which is the basis for the imputation of Christ's righteousness to the believer and which corresponds with the adoption (adoptio) of the believer, and the ongoing unio, or union, of the unio mystica, which continues concurrent with sanctification throughout the life of the believer'. ${ }^{128}$ Concluding his examination of numerous Johannine and Pauline passages, Demarest affirms that "relational images suggest that "in Christ" should be understood in a subjective or experiential sense; the data does not allow us to limit the

\footnotetext{
124 For recent discussions of the union with Christ see: Demarest, Cross, 313-43, Reymond, New Systematic Theology, esp. 736-39, and Pannenberg, Systematic Theology, 3.196-202, 237-44.

125 Berkhof, Systematic Theology, 448-49.

126 Hoekema, Saved by Grace, 55. Similarly Murray, Redemption, 161-73.

127 Demarest, Cross, 323. Also Gaffin, Resurrection, 50-52 about experiential union and 53-58 about existential union.

128 Muller, Dictionary, 314.
} 
"in Christ" motif strictly to the formal or objective meaning of the believer's new situation in the state of salvation'. ${ }^{129}$ S. B. Ferguson summarises: 'The blessings of salvation become ours through the Spirit, exclusively, immediately, simultaneously and eschatologically in Christ.' ${ }^{\prime 30}$

Reformed scholastic theology added to the concept of unio mystica the qualifying phrase sive praesentia gratiae tantum to differentiate between the abiding union of believers with God and the hypostatic union of divine and human natures in Christ. Calvin may be numbered among the proponents of experiential union as he opened his discussion of union with Christ: 'First, we must understand that as long as Christ remains outside of us, and we are separated from him, all that he has suffered and done for the salvation of the human race remains useless and of no value for us. ' ${ }^{131}$ Thus preserving the Christ-centredness of our salvation prevents us from isolating faith in Christ the Saviour and obedience to Christ the Lord that the Grace Evangelical Society has done.

Thus whether we take union with Christ in its wider or narrower sense, it always represents a comprehensive idea. Most of us would agree with R. L. Reymond that 'it is an all-embracive relationship in its soteric references, which God takes up into and includes within all that he has done, is doing, and will do in behalf of the sinner (see Eph. 1:3: "every spiritual blessing in the heavenly realms in Christ")'. ${ }^{132}$ Even the proponents of the experiential union who interpret it in its narrower sense, acknowledge that 'union with Christ was planned in eternity past in the sovereign counsel of God (Eph 1:4; cf. John 17:2), was objectively factualized via Christ's death and resurrection (Rom 6:5), and is subjectively realized by the baptizing ministry of the Spirit in individual lives (1 Cor 12:13)'. ${ }^{133}$ Since we have defined union with Christ as well as perseverance in comprehensive terms as an 'all-

129 Demarest, Cross, 329.

130 Ferguson, Holy Spirit, 102.

131 Calvin, Institutes, III.I.1. After him R. L. Dabney affirmed that union with Christ results in the application of full redemption to the sinner: 'justification, spiritual strength, life, resurrection of the body, good works, prayer and praise, sanctification, perseverance'. (See his Lectures in Systematic Theology [Grand Rapids: Zondervan, 1972]: 615. According to A. H. Strong 'union with Christ... is begun in regeneration, completed in conversion, declared in justification, and proved in sanctification and perseverance' in his Systematic Theology [Valley Forge: Judson, 1907]: 795).

132 Reymond, New Systematic Theology, 736.

133 Demarest, Cross, 324. 
embracive relationship' we have prepared the ground to observe whether there is and what is the difference between them.

Using the terms from Reymond's definition of union with Christ, we adapt them and affirm that perseverance is an all-embracive relationship in its soteric references between the beginning of the spiritual life and the physical death of the believer. Therefore perseverance is a sub-entity of the union with Christ. Even if union with Christ was interpreted as beginning at regeneration, it does not stop at the death of the believer but continues in its fuller sense in future eternity. We do not agree with Berkouwer that perseverance continues on into eternity. ${ }^{134}$ It is irrelevant to speak about the perseverance of the believer after his physical death since there is no discouragement, difficulty, temptation and persecution - there is no sin-to withstand. In positive terms, if perseverance is defined as 'steadfast pursuit of an aim', ${ }^{135}$ there is no more need of perseverance since the aim is achieved.

If we further develop our pentagonal diagram of the ordo salutis by adding to it a dynamic element and acknowledging the above described relation of perseverance to union with Christ, it will result in the following illustration that we may call The Cup of Salvation (Fig. 4). This illustration maintains our comprehensive definition of perseverance embracing the progressive nature of regeneration, conversion, justification, sanctification and glorification. At the same time it illustrates the need for growth in all of these aspects. Included in it is a constancy, a continuity, and a certainty that transcends the incidental and fragmentary aspects of our experience. ${ }^{136}$ Perseverance as a subentity of the believer's union with Christ maintains the direct link of perseverance to the person and work of Christ as is clear from the illustration. At the same time it reflects perseverance as a gift of God and a responsibility of the believer. He is preserved by the power of God because of the unceasing intercession of Christ. Being preserved by God, the believers persevere. The doctrine of perseverance within this ordo does not allow viewing the believer's life as a collection of discrete fragments of divine preservation and human failures and returns to faith, but rather as that life which participates in the

134 G. C. Berkouwer, Faith and Perseverance (Grand Rapids: Eerdmans, 1958): 10. 135 'Perseverance' in The Shorter Oxford English Dictionary on Historical Principles (2 vols.; Oxford: Clarendon, 1972).

136 Berkouwer, Faith and Perseverance, 9. 
communion of the Spirit. ${ }^{137}$ Different sizes of The Cup in case of individual believers reflect the role and importance of the believer's effort and responsibility in persevering. In this sense we affirm that 'we are responsible to persevere, but not for perseverance'. ${ }^{138}$ It has become obvious from the illustration that the same or similar relation exists between perseverance and other doctrines of salvation as between union with Christ and these doctrines. ${ }^{139}$

137 Berkouwer, Faith and Perseverance, 236.

138 M. S. Horton, Mission Accomplished (Nashville: Thomas Nelson, 1986): 136.

139 The relations of union with Christ are concisely described in Demarest, Cross, 33638. 
Fig. 4: The Cup of Salvation

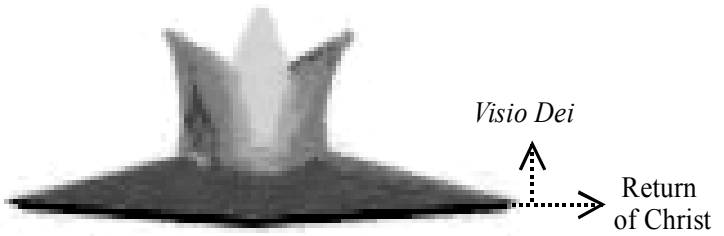

Consummatio salutis

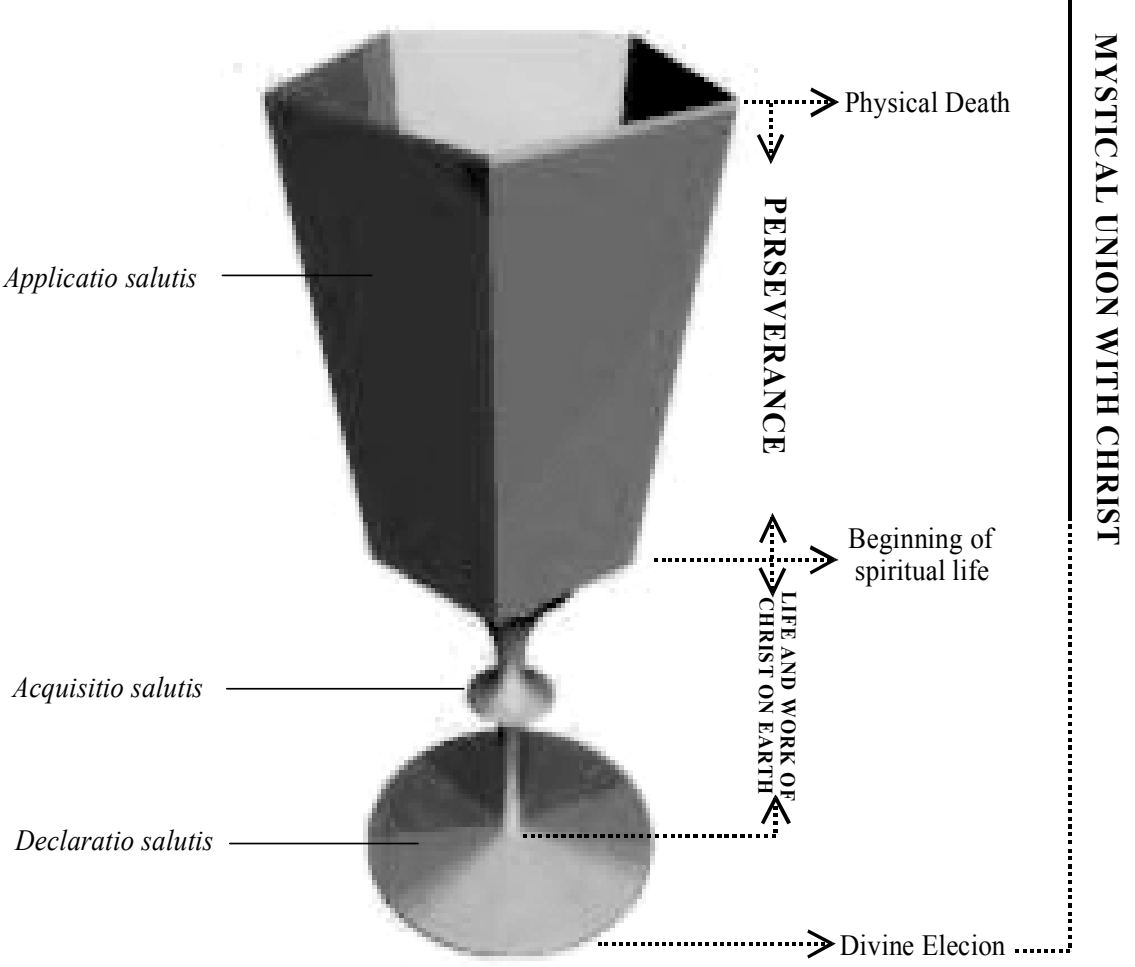

